\title{
Solidarity, Dominance, and the Taxation of Bequests
}

\author{
S. STEWART BRAUN \\ Australian Catholic University
}

\begin{abstract}
In his new book, The Inheritance of Wealth, Daniel Halliday (2018) argues that the taxation of bequest and inheritance is justified on the grounds of preventing dynastic concentrations of wealth harmful to both democratic equality and fair equality of opportunity. Although Halliday's claims are convincing, he neglects the role that solidarity should play in justifying a robust tax on bequest. In this paper, I develop an argument for taxing and regulating bequest on the grounds of solidarity, linking the argument back to the thought of both Marx and Rawls.
\end{abstract}

Keywords: solidarity, community, bequest, inheritance, domination, exploitation.

\section{INTRODUCTION}

Concerns regarding the impact of bequests and inheritance upon society are not new. For instance, philosophers as distinct as Mill (2004), Marx (1869 \& [1867] 2000), and Rawls (1999) have all opposed unregulated forms of inheritance and bequest. However, there may be good reason for renewed worry since, as Thomas Piketty (2014) has famously shown, there is a real danger that the rapid increase in income and wealth inequality portend the transformation of many liberal democracies into oligarchic, rentier societies in which returns to capital outstrip labour in terms of national income. Absent a robust and effective tax on bequest and inheritance, that possibility becomes more likely.

There are several ways to justify effective or robust taxation ('regulation' or 'taxation' for short) of bequests and inheritances ('bequest' for short). For example, one could press a predominately economic argument that criticizes bequest on the grounds of purported inefficiency. Because bequest and inheritance are gifted largely regardless of financial acuity, the wealth could be squandered. Better to tax it, and use the proceeds in 
ways designed to improve education, upgrade infrastructure, or provide start-up grants for deserving entrepreneurs. ${ }^{1}$ Bequest could also be addressed as a matter of justice; there are several well-known ways to show that justice demands effective regulation or taxation of bequest. One option is to adopt the left-libertarian view that persons have an equal and original right to worldly resources and that, consequently, a tax on bequest simply returns resources to their natural, un-owned state. ${ }^{2}$ Another way is to approach matters from a luck egalitarian perspective and claim that, because receipt of a bequest amounts primarily to a contingent and lucky occurrence, much of it can be taxed away. ${ }^{3}$ Finally, one might also take a broadly Rawlsian approach (1999) and ground the tax on the concern that bequest perpetuates undeserved wealth inequalities damaging to the ideals of fairness and democratic equality.

In his timely and sure to be influential new book, The Inheritance of Wealth, Daniel Halliday (2018) largely follows the fourth, broadly Rawlsian path, arguing that an effective tax on bequest and inheritance is justified in order to prevent dynastic concentrations of wealth harmful to social equality. More specifically, Halliday contends that by its nature an inheritance is undeserved and that it causes economic segregation, which undermines democratic equality and fair opportunity. ${ }^{4}$ Although Halliday's claims are convincing, he neglects to consider an alternative, but no less powerful approach that could be used to further strengthen the argument against bequest and inheritance.

That alternative approach is what I call the 'solidarity approach' because it grounds the regulation of bequest on the moral concern that large bequests undermine a society's sense of community and, ultimately, its ability to mutually support its members. This approach accepts Halliday's empirical claim that bequest creates economic segregation, but it differs insofar as it locates what is wrong with bequest in terms of bequest's negative impact on communal solidarity-not just its harm to equality of opportunity and democratic equality. Although I say more about the term 'community' below, I understand community as being characterized by two elements, namely, 1) a sense of mutual understanding and 2) a sense of common purpose or commitment. Accordingly, if a society lacks these communal elements, then its members will also lack an effective sense of

\footnotetext{
The general idea that bequeathed property might not be productively employed is seemingly present in Smith's criticism of entails. Smith thought that by blocking the free dispersal or sale of land, entails prevented the land's productive employment. See: Smith (1981: $384 \mathrm{ff}$.)

For instance, see: Steiner (1994: 258).

For instance, see: Rakowski (1991) and Alstott (2007).

As Halliday (2018: 152-3) notes, his argument combines both luck egalitarian and social egalitarian perspectives.
} 
solidarity. Even though solidarity can itself be understood in various manners, the use of that term is intended to pick out the general idea that persons are mutually committed to the good of one another. ${ }^{5}$

As I go on to explain, concerns regarding bequest's impact on solidarity are operationalized by reference to relationships of economic dominance, which are themselves characterized by forms of exploitation and social alienation. So, unregulated bequest does not just allow "certain groups... to monopolize superior life prospects for their members," (emphasis mine) as Halliday (2018: 101) puts it, bequest also hinders the development of a community ethos and a sense of mutual support. The taxation or regulation of bequest may therefore be constructively understood as a commitment to communal solidarity because privately controlled wealth is re-invested back into the community. The regulation of bequest does not need to be understood solely or primarily in terms of securing fair competition for valued social positions or standing.

The solidarity approach is obviously influenced by Marxist concerns about community, as well as the negative impact of domination and alienation on communal solidarity. As such, the argument is grounded in a broader set of moral concerns that are not effectively captured by the liberal egalitarian focus on equality of opportunity or democratic equality. In that sense, the solidarity approach stands distinct from Halliday's approach. And even though, because he employs the concept of economic segregation, Halliday's argument is somewhat amenable to concerns about solidarity or community, it ultimately fails to adequately identify the negative impacts of economic segregation and to take full advantage of the critical power afforded by recognition of that problem. Unregulated bequest, through the economic segregation it creates and sustains, damages the fabric of community.

In what follows, I briefly examine the Marxist argument against bequest from which the solidarity approach draws inspiration. I then further develop the solidarity approach, demonstrating how it can be used to further the moral critique of unregulated bequest.

\section{MARX ON BEQUEST AND INHERITANCE}

Marx was clearly opposed to unregulated bequest. And, although he rightly did not view it as a cause of capitalists' private ownership over the means of production, he did think that it sustained the capitalist system. As he states (1869: 1), "Inheritance does not create that power of transferring the 
produce of one man's labor into another man's pocket-it only relates to the change in individuals who yield that power". For Marx, bequest was a legal convention developed to retain private control of capital and productive assets. So, even though in a communist society there would be almost no need for a tax on bequest-private ownership in the means of production being eliminated-regulating/ending bequest was still a potentially useful "transitory measure" to communism because it would prevent the maintenance of the capitalist system (1869:2).

Although Marx paid almost no attention to bequest in Capital, he does note that the "division of property within capitalist families" plays a large role in the accumulation of capital ([1867] 1990: 776). This is important because according to Marx, "Every accumulation becomes the means of new accumulation. With the increasing mass of wealth which functions as capital, accumulation increases the concentration of that wealth in the hands of individual capitalists..." ([1867] 1990: 776). So, the point is that bequest or inheritance perpetuates the capitalist system by enabling donees or heirs to attain the level of wealth necessary to function as capitalists. Therefore, Marx's argument can be understood as demonstrating that large bequests both retain and reinforce the division of society into separate classes, namely, the workers and capitalist owners. This point is obviously commensurate with Halliday's claim that bequest creates economic segregation. The difference is, of course, the points of emphasis. Halliday emphasizes the negative impact of segregation on something like equal opportunity and political standing, whereas Marx focuses on how this division strips workers of the control of their labor and life activity, all to the detriment of a truly human community.

According to Marx, capitalists dominate laborers and thereby exploit them by preventing them from obtaining the means necessary to employ their labor freely and in a manner conducive to their self-development. As Marx states in Capital, "The capital relation presupposes a complete separation between the workers and the ownership of the conditions for the realization of their labor" ([1867] 1990: 874). To better understand this position, it is necessary to say something briefly about Marx's concept of alienation. As Marx saw it, capitalism prevented workers from acting as an autonomous "species being" that constructs social and material life in community with others. Marx ([1932] 1975: 276, 277) describes his thought as follows:

Yet the productive life is the life of the species. It is life-engendering life. The whole character of a species-its species-character-is contained in the character of its life activity; and free, conscious activity is a man's species-character... It is just in his work upon the 
objective world, therefore, that man really proves himself to be a species-being.

And later in summary:

In fact, the proposition that man's species-nature is estranged from him means that one man is estranged from the other, as each of them is from man's essential nature. The estrangement of man, and in fact every relationship in which man stands to himself is realized and expressed only in the relationship with which a man stands to other men. ([1932] 1975: 277).

So, the problem is two-fold. In the first place, because workers in a capitalist society lack control over their work and its product-laboring only for a wage - they lack autonomy and cannot properly develop their abilities, nor engage in meaningful activity. Second and relatedly, when workers are alienated, they stand estranged from their fellow society members. This is because Marx thought that only in a social relationship, where persons were not simply labouring for a wage, would the instrumental nature of work and much of life activity disappear, such that persons would appreciate their own activity and the activity of others as an expression of the value and capabilities of the person. In other words, only in relationship characterized by solidarity and common commitment-not one characterized by economic exploitation and the struggle for a living wage - could persons engage one another constructively and reciprocally so as to encourage the mutual development of self. To the extent that bequest enables the capital relation to perpetuate itself, it contributes to harms embodied in the concept of alienation.

So, looking back over Marx's criticism of bequest, we can observe that bequest is to be abolished or heavily regulated because it plays a role in securing the "capital relation" in which the worker is economically dominated and exploited by the capitalist owner. By perpetuating this relationship and the class division that follows from it, bequest harms the worker by leaving her alienated and unable to realize the value inherent in her own life activity and the activity of others. Therefore, although bequest is not the ultimate cause of social estrangement, it is a major contributing factor.

\section{THE SOLIDARITY APPROACH}

The problem with unregulated bequest is, as both Halliday and Marx point out in their own way, that it helps to sustain a wealthy, propertied class that possesses significant financial resources in comparison to the broader 
population. In Marx's analysis, this leads to a relationship of exploitative domination and a society characterized by antagonistic social relations in which persons cannot come to recognize the value in other's activity, nor realize the value of their own activity. In Halliday's analysis, unregulated bequest leads to unjustified advantages that work against something like fair equality of opportunity. However, Halliday is also keenly aware of the impact of bequest on social relations. Important to Halliday's argument is his worry about how economic segregation can separate persons from different economic classes, especially the rich from the poor, such that the rich have little social interaction and cannot understand nor empathize with the situation of those living in poverty. According to Halliday (2018: 113), at its worst, this separation can lead to the "demonization of the poor" in which those living in poverty are depicted as lazy, intellectually slow, or otherwise somehow deserving of their condition. The end result is government policies that are either punitive or non-responsive to the needs of poorer members of society. What Halliday seems to find most objectionable about this situation is that it hinders the possibility that the poor will receive the assistance and support they need, and that, consequently, they will continue to lack meaningful opportunity and equal status. However, his perspective is also in line with Marx's worries. Economic segregation and the demonization narratives that accompany it, clearly damage social solidarity and the idea of mutual support by removing a class of persons from the ambit of social concern.

So, although Marx emphasizes more directly the problem of subjugation or domination, much of what Halliday says is consistent with that position. Nonetheless, Halliday does not really discuss the importance of community and solidarity. This is somewhat regrettable because it could serve as another plank in his argument against unregulated bequest and inheritance. Class division or economic segregation seems particularly bad, not just because it can negatively and unfairly impact the life opportunity and status of the impoverished in comparison to others, but precisely because it separates people from each other, i.e. from the good of community. I explain this thought more thoroughly below.

A community, as opposed to a formal political society, is characterized by two elements: 1) a sense of mutual understanding or shared ability to relate to fellow members and, 2) a common commitment or aim that serves to orient the wills of the individuals away from an exclusive focus on the self and toward a broader more comprehensive, shared goal. A community is, therefore, characterized by relationships of solidarity between its members because there exist shared understandings and a common aim which link persons together. All of this creates a sense of mutual 
commitment and support. ${ }^{6}$ But why think that community and the relationship of solidarity that it grounds are valuable?

I think there are two answers from within the Marxist tradition. The first is supplied by Marx himself and depends on the idea that humans are communal and find meaning or value through relationships and activities with others. In other words, communal solidarity is good because it allows for the development of the individual as well as the society of which he or she is a part. Therefore, community is both instrumentally and intrinsically valuable. It is instrumentally valuable insofar as it allows for and encourages the development of the individual, and it is intrinsically valuable because persons are interconnected and communal by nature-so community is a good itself. In a passage describing the communal nature of persons Marx ([1932] 1975: 298) declares:

Just as society itself produces man as man, so is society produced by him. Activity and enjoyment, both in their content and in their mode of existence are social: social activity and social enjoyment. The human aspect of nature exists only for social man; for only then does nature exist for him as a bond with man-as his existence for the other and the other's existence for him"?

Marx's point seems to be that our understanding of ourselves, our plans, and projects-our life activity—cannot be comprehended apart from community. As much as humans create community, they are also created by it or may be understood partly as a product of it. Although this claim is primarily descriptive, it needs to be understood in the broader context of Marx's claim that the good for persons is tied to their activity as a 'species being' that finds purpose and meaning in the use of its productive and creative capacities in community with others. This allows for the inclusion of a strong normative element. So, if the descriptive claim that persons create and are created by community is true, then persons cannot be understood, nor find value in their lives-that is to say that they cannot properly self-develop or self-realize-without engaging in a range of mutually committed and meaningful human relationships because it is only through those relationships that value can be understood or apprehended. As Marx might put it, persons cannot be complete or truly human in the absence of communal relationships, and a society itself will be impoverished if it does not develop a sense of solidarity and mutual concern-it will not be a true human community.

\footnotetext{
As Habermas (1990: 47) describes solidarity, it "concerns the welfare of consociates who are intimately linked in an intersubjectively shared form of life".

What is referred to in the text as 'social' is what I am calling 'community'. Marx is discussing the social conditions that are necessary to community.
} 
The second answer is supplied by G.A. Cohen who argues that a commitment to community is necessary for a truly egalitarian society. In his last book, Why Not Socialism, Cohen (2009) contends that an egalitarian society will necessarily be characterized by a community ethos. More specifically, he argues that inequalities must be constrained by a community principle that does two things: 1 ) limit inequalities (that result from option luck) so that persons are capable of relating to the daily experience of others, and 2) that opposes a strict market ideology, so that persons are motivated by the idea of serving one another from a genuine commitment to cooperation. As Cohen (2009: 18) puts this last point, "A nonmarket cooperator relishes cooperation itself: what I want as a nonmarketer, is that we serve each other..." For Cohen, then, an egalitarian society will be one in which community is valued and solidarity is present. This, however, does not mean that community and solidarity are purely instrumental values, useful only for producing equality. Rather, the point is that society cannot be truly equal unless persons understand community to be valuable itself. In other words, egalitarian social relationships, on Cohen's understanding, depend on community.

Although Marx and Cohen emphasize different elements of community-Marx tying it to human development, while Cohen links it more directly to equality - they both demonstrate that a sense of solidarity, arising from community, is necessary for the achievement of important human goods and a truly just society. More specifically, both agree that mutual commitment and cooperation are necessary elements in a morally justifiable society. A society lacking these elements will be less equal, less supportive of human projects, and, generally, a worse society.

So, the outlines for the solidarity approach should be coming into focus. In a true community there exists a sense of mutual understanding, commitment, and support that enables persons to approach each other as equals and to develop their projects and goals together in a vibrant society. In other words, a community is characterized by a sense of solidarity that benefits both individuals and the community itself. This means that in a community, members benefit not at the expense of, regardless of, or despite other members (as in an economically segregated society), but rather they benefit through and with others. An effective tax on bequest, which is properly redistributed to ensure that all persons have access to things like robust education and training schemes, access to productive assets or income bearing capital, housing, and opportunity for meaningful work, stands as a particularly concrete way to reduce domination and realize the 
ideal of mutual support and solidarity that characterizes community. ${ }^{8}$

If particular members of a society have gained substantial amounts of wealth that can be passed on, a commitment to solidarity entails that this wealth should be used to promote the common good by upbuilding community infrastructure and assisting the vulnerable. By effectively taxing and redistributing large bequests, society can ensure that those who have done well from their productive engagement in society are helping those that for one reason or another lack access to valuable and productive resources. A society characterized by a strong sense of community and solidarity should be willing to institute policies that support less fortunate members, especially when any cost is easy to bear. Again, the taxation and proper redistribution of bequest epitomizes this idea. Since in a case of bequest the donor is deceased, the wealth clearly has not been used by the donor. ${ }^{9}$ Consequently, spreading the benefits of that wealth to others stands as a clear way to promote community and cooperation by ensuring that all of society's members are capable of accessing the resources required to develop their abilities and participate productively in society. ${ }^{10}$

Another way of putting this point is to appeal to Cohen's (2008) idea of a "justificatory community". According to Cohen, a justificatory community is one in which there is a norm of comprehensive justification, by which he means that the members of the community are capable of interpersonally justifying a social policy to each other (2008: 42-43). A policy of not taxing or minimally taxing large bequests, given the argument above, cannot be comprehensively justified because the rich are preventing a fairer and more communally beneficial distribution of socially generated wealth. It is as if the rich are saying to the poor: 'Although I have benefitted from my engagement in society, I am not going to share my outsized returns despite your impoverished situation and the reality of broader community needs.' But as Marx has argued, persons and their productive activity are always tied up with and dependent on society. In rejecting an effective tax on bequest, then, the rich are unjustifiably ignoring the mutual engagement

\footnotetext{
How much revenue could an inheritance tax expect to generate? Obviously, the answer to this question depends on the structure of the tax. However, as a starting point we could take Edward Wolff's (2015: 244) calculation that an inheritance tax with a \$500,000 (USD) exemption and top marginal rate of $45 \%$ would raise $\$ 31.6$ billion. Although the money raised is not insubstantial, a more progressive structure is almost certainly required to meet important moral concerns.

For an argument detailing why the donor has no right to provide an unfettered bequest, see: Braun $(2012 ; 2016)$.

10 Because bequest is being taxed, not banned, persons can still express solidarity with others through charitable bequests. In other words, a tax on bequest does not leave the promotion of solidarity entirely in the hands of the impersonal state. I thank an anonymous referee for asking me to address this issue.
} 
that allowed for their prosperity. Per Cohen's argument, then, unregulated bequest shows the rich to be out of community with the poor-the rich fail to take the poor's concerns seriously and indirectly cause, through the rejection of a tax on bequest, a continuation of the poor's situation. ${ }^{11}$

Although the solidarity approach provides a clear foundation for the taxation of bequest, it may be objected that it is infeasible because it is grounded on a moral attitude that might not be widely shared. As a critic might argue, we should not expect the bonds of solidarity to extend across a large and diverse society-it is simply too unrealistic. It could therefore be contended that it is a mistake to attempt to ground policies like the taxation of bequest on the idea of solidarity or community, since the requisite bonds simply do not exist or are not of sufficient strength. Although solidarity may be constrained in larger, more diverse societies, this criticism is radically overdrawn. In particular, it ignores three important points that demonstrate how solidarity can develop across a large society. First, it neglects the fact that solidarity need not require a shared identity and that local communities can provide the requisite connectedness for solidarity. Second, it tends to assume that members must share an external or overarching end that they all accept, when, in reality, community members' shared ends may be internally oriented. Thirdly, it disregards the fact that an individual's success depends to a substantial degree on the success of others. Each point is defended below.

It is true that the size and diversity of many modern states can work to hinder the development of a robust sense of community and solidarity, especially when it is understood simply as being grounded in a shared identity. However, that fact does not preclude the development of a local sense of mutual concern that can be extended to encompass the larger community. Persons are often rightly more connected to those in their local community with whom they have some contact. But given that a large society is composed of intertwined communities that confront similar social issues and concerns, a local sense of solidarity is capable of being extended through the larger community as well. For instance, although I may not know, nor share many commonalities with a miner on the opposite end of the country, I am much more likely to know or be aware of the situation of industrial workers in my city. The concern I feel about the situation and treatment of those industrial workers in my local area gives me the ability, although it may be more attenuated, to appreciate the plight of the miners confronting similar issues.

11 One might ask how the rich cause the situation. I think it is beyond dispute that wealth grants political power. If the wealthy acquiesced to an effective inheritance tax it would be adopted. For empirical support, see: Winters (2011) and Piketty (2020). 
So, it should be clear that I am not describing what Durkheim (1973: 84) has termed "mechanical solidarity," which he describes as a form of group cohesion based on a shared identity. That type of solidarity is probably a non-starter in a large community. Rather the point is that even in large diverse societies, there are linkages and interconnections between people, especially in their local community, that allow for mutual understanding and concern to develop. That concern can then be extended across the broader society as a result of persons' ability to empathize with and appreciate the difficulties faced by others. ${ }^{12}$ In short, opponents of solidarity are wrong to think that it must be grounded in a shared identity. Although a sense of shared identity can help to facilitate solidarity, it is not necessary since solidarity can be developed through a recognition and appreciation of the needs and struggles of other community members, be they near or far.

Sometimes it is claimed that what binds persons together into community is a shared end. For instance, Rawls (1999: 462) has contended that in a society structured according to 'justice as fairness', persons share the end of a commitment to justice itself. As he states, "the successful carrying out of just institutions is the shared final end of all members of society". Those who wish to criticize the solidarity approach may assume, then, that this shared end must be an overarching or external end that is shared in common by all. For example, to have the most technologically advanced military in the world could serve as an overarching shared end. Given the size and diversity of modern states, it might then be argued that there is, in fact, no shared end. Hence, the community necessary for the development of solidarity is not possible.

But assuming it is true that a community must share an end of some type, it is not the case that this shared end must be overarching in the sense described above. As Daniel Brudney (1997: 397) and has argued in the case of both Marx and Rawls, community members may share an "internally oriented" end that is constitutive of their relationship and is not overarching. An internally oriented end is one that specifies the internal nature of society itself. It is not an external goal that all seek to promote, like the example of achieving the most advanced military, but rather an end around which social relations are oriented. For instance, deep or robust friendships are typically oriented around an internally shared end of mutual support that serve to structure and sustain the friendship. In contrast, a friendship based solely on a shared external goal is likely only to last until the goal is

12 I take it that the human ability to empathize is non-controversial. However, this is not to deny that persons can do a better or worse job at it. For an initial discussion of how it might function, see Hume's (1998) discussion of what he calls "sympathy". 
attained. As Brudney explains it, in a Marxist or Rawlsian society the shared end is to live in a community that embodies either Marxist commitments to self-realization or Rawlsian commitments to justice. This is an internally shared end that grounds a strong form of communal engagement requiring sustained interaction and cooperation. Consequently, since members of a Rawlsian or Marxist society hold internally oriented shared ends there is no reason to accept the criticism that solidarity or a sense of community is not possible.

The proposed criticism that solidarity cannot be developed or sustained in large diverse societies is also undermined by the fact that it adopts or presumes an individualism that is not borne out by reflection on human experience and activity. This is a point that Rawls (1999: 459) seems to be keenly aware of when he describes a social union as "the community of humankind the members of which enjoy one another's excellences...". (More below.) Marx is also clearly at pains to demonstrate this point in the 1844 Manuscripts. According to Marx ([1932] 1975: 299), "the individual is the social being" and even when an individual is working largely independently, that individual's goals and the value attributed to the work are socially influenced. As Marx ([1932] 1975: 298) states in describing independent work, even though it is not performed in "direct community with others," it is still communal because "my own experience is social activity and therefore that which I make of myself, I make of myself for society..." Marx's point is that it makes no sense to speak of the individual as separate from the community because, as noted earlier, understandings of value and purpose are constructed through and in relation to social engagement. In other words, an individual can only identify him or herself as an individual with their own values in relation to the values and selfidentity of others.

Given these three points, there is no reason to assume that the solidarity approach cannot be used to ground the regulation and taxation of bequest, even in large, diverse societies. Solidarity need not be based on a shared identity or culture, nor does it require a shared overarching end. It is grounded in the interaction of persons in the local community, the human capacity for empathy, our social nature along with our natural proclivity to engage in productive activity, especially as it relates to and is informed by others. The effective taxation of bequest frees up wealth that can then be employed to improve the situation of those in our communities that require additional assistance. A failure to do so ipso facto represents a lack of solidarity with, and commitment to, our fellow community members. 


\section{JUSTICE, SOLIDARITY AND BEQUEST}

In closing, I want to say a few words about how the solidarity approach relates to Halliday's argument. Halliday's argument is largely an argument about the injustice of improperly regulated or taxed bequest. Large bequests, which by their nature are arbitrary and a fact of luck, lead to economic segregation that damages something like fair equality of opportunity and democratic equality. The first thing to say is that I think Halliday is absolutely right, viz. large, unregulated bequests clearly work against the idea of a fair and equal society. There is no good reason for countries like Australia and the U.S. to fail to properly tax and regulate

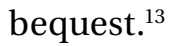

However, Halliday's argument fails to appropriately recognize the full moral problem with economic segregation. The problem is not just that some persons suffer from a lack of opportunity and weakened status compared to others. Rather the issue is that economic segregation, aided and abetted by bequest, works against the formation and extension of community. As such, it leaves persons isolated from valuable interpersonal relationships and forms of cooperation. It also leaves them incapable of the development of self that goes with community.

Now, for the sake of argument at least, Halliday could hypothetically respond that from a liberal perspective community and personal development are of no interest or concern. However, I think that would represent an impoverished view of the liberal egalitarian tradition (and, of course, it may be a position Halliday himself rejects). Liberals no less distinguished than Mill and Rawls have emphasized the importance of community and self-development. ${ }^{14}$ For instance, in an important footnote detailing the concept of a social union, Rawls (1999: 459-460, note 4) claims that "persons need one another since it is only in active cooperation with others that one's powers reach fruition. Only in a social union is the individual complete". So like Marx, Rawls identifies community as necessary and important to the individual. Without a reciprocal community, an individual's development is stunted and their ability to accomplish their aims are severely impeded. It is the acknowledgement of

\footnotetext{
13 Australia lacks any direct federal tax on bequest and inheritance, and currently no states or territories have any form of direct taxation on bequest or inheritance. See: Australian Taxation Office (2019), Australian Government, Canberra, https:/www.ato.gov.au/general/capital-gains-tax/ deceased-estates-and-inheritances/. Although the U.S. does have an estate tax, for all intents and purposes it is rather useless since it grants an exemption of up to $\$ 11.4$ million per individual donor. See: Internal Revenue Service (2019), United States Government, Washington , D.C., https:// www.irs.gov/businesses/small-businesses-self-employed/whats-new-estate-and-gift-tax

14 See: Mill (2004); Rawls (1999).
} 
this type of mutual dependency and connectedness that can serve as the ground for solidarity and community. And as has already been discussed above, in a just, well-ordered society, Rawls views cooperation as an internally shared end. Moreover, Rawls also claims that the difference principle, properly understood, is consistent with fraternity because it encapsulates the general idea that in relationships characterized by mutual concern, persons will not accept benefits that leave others disadvantaged (1999: 90). So, although community is not something that is emphasized in liberal egalitarian thought, a concern for community does not run contrary to that strand of thinking (at least as community is conceptualized in this paper).

So, the point is that Halliday fails to fully recognize the harm done by bequest and, accordingly, misses an opportunity to further criticize the practice. And although, from his perspective he may not accept the more robust sense of community developed in Marxist thought, certainly an attenuated acknowledgment is within Halliday's grasp. At bottom, then, Halliday's argument could be strengthened or supplemented by an acknowledgement that the proper taxation of bequest represents a commitment to others in society and it should be welcomed on those grounds. A society that allows lucky heirs to benefit at the same time it ignores the needs of other portions of the population, is one that fails to display solidarity and mutual concern. In short, a society that fails to effectively tax or regulate bequest fails the test of community.

\section{BIBLIOGRAPHY}

Alstott, A., 2007: “Equal Opportunity and Inheritance Taxation”, Harvard Law Review 121: 470-542.

Australian Tax Office, 2019: "Deceased Estates and Inheritances", Australian Government, Canberra, URL = < https://www.ato.gov.au/general/capital-gains-tax/deceasedestates And inheritances/>.

Braun, S., 2012: "Historical Entitlement and the Practice of Bequest: Is There a Moral Right of Bequest?", Law and Philosophy 29: 695-715.

-2016: "Liberty, Political Rights and Wealth Transfer Taxation", Journal of Applied Philosophy, 33: 379-395.

Brudney, D., 1997: “Community and Completion”, in Reclaiming the History of Ethics: Essays for John Rawls, eds. A. Reath, B. Herman and C. Korsgaard, Cambridge: Cambridge University Press.

Cohen, G.A., 2008: RescuingJustice and Equality, Cambridge, Mass.: Harvard University Press.

-2009: Why not Socialism, Princeton: Princeton University Press.

Habermas, J., 1990: “Justice and Solidarity: On the Discussion Concerning Stage 6”, in Hermeneutics and Critical Theory in Ethics and Politics, ed. M. Kelly, Cambridge, Mass.: MIT Press, 1990. 
Durkheim, E., 1973: On Morality and Society, Chicago: University of Chicago Press. Halliday, D., 2018: The Inheritance of Wealth: Justice, Equality and the Right to Bequeath, Oxford: Oxford University Press.

Hume, D., 1998: An Enquiry Concerning the Principles of Morals, ed. T. Beauchamp, New York: Oxford University Press.

Internal Revenue Service, 2019: "What's New-Estate and Gift Tax", United States

Government, Washington, D.C., URL $=<$ https://www.irs.gov/businesses/small businesses-self employed/whats-new-estate-and-gift-tax $>$.

Marx, K., [1867]1990: Capital, vol. I, London: Penguin Classics.

-1869: "Report of the General Council: The Right of Inheritance", Report of the Fourth Annual Congress of the International Workingmen's Association, URL $=<$ https:// www.marxists.org/history/international/iwma/documents/1869/inheritance report.htm>.

— [1932] 1975: "Economic and Philosophical Manuscripts of 1844”, in Marx Engels Collected Works, vol. 3, New York: International Publishers.

Mill, J.S., 2004: Principles of Political Economy, New York: Prometheus Books.

Piketty, T., 2014: Capital in the Twenty-First Century, trans. A. Goldhammer, Cambridge Mass:Harvard University Press.

-2020: Capital and Ideology, trans. A. Goldhammer, Cambridge Mass.: Belknap Press of Harvard University Press.

Rakowski, E., 1991: Equal Justice, New York: Oxford University Press.

Rawls, J., 1999: A Theory of Justice, Oxford: Oxford University Press.

Scholz, S., 2015: “Seeking Solidarity”, Philosophy Compass 10: 725-735.

Smith, A., 1981: An Inquiry into the Nature and Causes of the Wealth of Nations, Indianapolis: The Liberty Fund.

Steiner, H., 1994: An Essay on Rights, Cambridge, Mass.: Blackwell Publishers.

Vrousalis, N., 2013: "Exploitation, Vulnerability and Social Domination", Philosophy and Public Affairs 41: 131-157.

Winters, J., 2011: Oligarchy, Cambridge: Cambridge University Press.

Wolff, E., 2015: Inheriting Wealth in America: Future Boom or Bust, New York: Oxford University Press. 